DOI: 10.20472/IAC.2018.043.022

\title{
DESERE KOKT
}

Central University of Technology, Free State, South Africa

\section{ESTHER PEARL PALMER}

Central University of Technology, Free State, South Africa

\section{IS IT POSSIBLE FOR UNIVERSITIES TO CREATE SPIRITUAL WORKPLACES?}

\begin{abstract}
:
The globalized world of work poses significant challenges to universities - ranging from increased digitalisation and virtualization, to greater diversity in student numbers, larger student intakes and the need for universities to continuously engage with business, industry and other external stakeholders. Contemporary universities have also developed a distinct managerial nature (managerilaism) which means they are increasingly managed like private sector organisations. This is in contrast to the collegial structures that prevailed in universities in previous generations. The shift from collegiality to managerilaism has implications for academics - specifically related to autonomy, moral, motivation and commitment. Based on the Communities of Practice as theoretical framework the paper proposes an emphasis on workplace spirituality as a means to compensate for the erosion of collegiality. It further provides suggestions to university management on how to create a spiritual workplace especially for academic staff.
\end{abstract}

\section{Keywords:}

workplace spirituality, universities, collegiality, managerialism, globalized world of work

JEL Classification: L20, L21, L30 
Globalization and the massive expansion of the Internet and Information Communication Technology (ICTs) have irrevocably changed human existence on a social and technological level. This also extends to organisations that continuously need to manage the new world of work that is characterized by increased digitalisation and virtualisation. In this sense, universities must consider the needs of business and industry in order to train and develop suitably skilled graduates. As universities are increasingly expected to be profit-driven more pressure is placed on especially academic staff in terms of generating additional income, securing competitive funding and delivering outcomes such as article publications, completed post-graduate studies, and the like. This is apart from the other duties expected from academics - that can range from teaching, administration, and curriculum development to community engagement and stakeholder interaction.

This is in contrast to the ethos of universities in previous generations, when so-called 'collegiality' was the main characteristic. Collegiality was typified by autonomy, long-term relationships, non-hierarchical structures, shared decision-making, informal relationships and mutual support. This has in the contemporary world been replaced by increased managerialism and universities that are managed like private sector businesses. Managerialism involves a more structured, competitive environment where academic staff is subjected to performance reviews, quality indicators, measurable outputs, less autonomy and more compliance to bureaucratic processes. It is thus safe to argue that managerialism has stripped universities, and specifically academic staff of their interdependent relationships and autonomy in favour of bureaucratic compliance to rules and regulations. Needless to say, increased managerialism has implications for the commitment and retention of staff, especially academics.

The question can thus be posed whether universities are able to create an environment where individuals can find purpose and meaning, especially since collegiality is diminishing. This can possibly be addressed by placing more emphasis on workplace spirituality. Workplace spirituality has gained prominence in the last decade giving credence to the innate need for humans to be engaged in their work and to make a significant contribution to their organisations. Workplace spirituality relates the desire of employees to perform meaningful work, to experience a sense of community with coworkers and to ascribe to the overall aims and goals of the organisation. Workplace spirituality is different from religion (that is concerned with faith) and spirituality (that implies the religious processes associated with organised religion). In debating this, the paper interrogates the question whether universities are able to create spiritual workplaces, especially for academic staff. 


\section{The evolution of universities}

The University of Bologna, Italy, was established in 1088 and is believed to be the first higher-learning centre referred to as a university in the Western World. Education at this university focused on logic, rhetoric, grammar and law, as well as medicine, mathematics, astronomy and philosophy (Clark, 2013). Oxford University is regarded as the Englishspeaking world's oldest university and its origin is estimated around 1096. During 1170 the University of Paris developed from the Catholic schools of Notre-Dame with Theology at it's centre. Universities in colonial America were established several centuries after those in Europe with Harvard being the first in 1636 (Clark, 2013).

European and African missionaries initially undertook the introduction of Africa's 'Western' style universities and Zeleza (2016) note that these missionaries were largely concentrated in the fast-growing settler colonies of South Africa, Algeria, Sierra Leone and Liberia. The teachings were mainly confined to the settler population. These early universities focused predominantly on religion and were initially established as organisations free from the direct control of the church or other religious institutions. The privilege of establishing such an institution was granted by the king or state which allowed for academic freedom to question, research and advance knowledge (Anderson, 2010). The number of universities was limited as the majority of the populations were iliterate.

The initial structuring and ethos of universities were collegial. Collegilaity places emphasis on scholarship, research, rational thinking, autonomy, long-term relationships, non-hierarchical decision-making, informal relationships and mutual support (Lynch, 2015). However, the largely unregulated work regimes of collegialism has in recent years made room for a more systematic approach to managing universities - labelled the managerial approach or managerialism (Alawaad, 2015). Managerialism has emerged from the influence of Catholic colleges and community colleges in the USA that placed an emphasis on management competence. Community colleges also grew from the elementary and secondary school system, and faculty members were mostly teachers, rather than scholars and academics.

Managerialism can be regarded as the adaptation of 'private sector tools in public sector organisations'. Managerialism finds meaning in the managerial elements like organising and evaluating work, an emphasis on output over input, close monitoring of employee performance, and the use of performance indicators and rankings. It further values fiscal responsibility and effective supervisory skills (Abramov, 2012). According to Lynch (2014) managerialism as a mode of governance is closely linked to neoliberalism. As neoliberalism find expression in market principles it assumes that private sector business principles of efficiency and productivity are superior to the way public bodies are governed. 
Due to the challenges of the globalised world of work unversities have no other option but to revisit their objectives and purpose (Deloitte, 2017). In their quest to address the demands of the knowledge economy universities need to prepare students for a demading and technology-driven work environment. This can only be realised if universities are responsive to the needs of business and industry within this knowledgedriven global setting. It is thus justified to agrue that the increased emphasis on managerialism can be attributed to the demands of the new world of work and the increasing pressure on universities to be responsive to market-related needs and meeting customers' expectations with respect to value for money.

In line with this, Lynch (2014) states that the impact of managerialism in education in general has been most evident in higher education over the last two decades. It appears that there is a global movement to change higher education into a marketable commodity. The modern university is thus characterised by changes in the traditional autonomy of academic staff. Increaed managerialm is evident in Jarvis's (2014) estimation that nearly half of the countries in the world have quality assurance systems or regulatory bodies that monitor quality in higher education. This indicates the extent to which managerialim has permeated its influence; leading to performance reviews, monitoring and assessment resembling the ways in which private companies are managed (Teichler, Arimoto, and Cummings, 2013).

\section{The unique nature of universities}

Universities can be considered as special organisations as they do not have the same profit-related focus of privately-owned businesses. Yet, managerialism is applied to universities as if they are private sector, profit-driven institutions. The next section unpacks the nature of universities and how they differ from private sector organisations.

Universities, as the custodians of knowledge need to serve society through their focus on teaching and learning (imparting knowledge and skills), research (finding new ways of progressing knowledge; using new knowledge to advance society through patents and intellectual property), and community engagement (interaction with business and industry and local communities to impart knowledge and skills) (Du Pre, 2010). Universities are thus unique organisational forms that simultaneously have several purposes as indicted above. Universities generally consist of heterogeneous groups of people that need to perform a wide range of activities; therefore, they can be regarded as Communities of Practice. Communities of Practice implies agreement and mutual understanding which forms the basis of how things are done. Communities of Practice further involve groups of people that share a passion for something (a craft or profession) and they interact regularly because of their common interest (Wenger, 2004). This is an aspect that are not necessarily part of private sector organisations with their profit-oriented focus. 
Modern universities are further characterised by high differentiation and low integration. High differentiation implies that the various departments or sections within universities often create their own ways of doing things (sub-cultures within the overall organisational culture). Low integration implies that the different departments or sections within universities are often not well coordinated and departments or sections operate in isolation. Due to this it may happen that academics rather conform to the values and expectations of their professional bodies as opposed to those of the university (Davies, Douglas, \& Douglas, 2007). Although vice-chancellors and deans are responsible for the institutional order, nothing authorises them to govern, in detail, the research and teaching conducted by academic staff. This is contradictory to managers in private sector organisations that strictly determine the everyday actions of employees.

Academics are often characterised by their individualism and their reluctance to be team players (Nagy \& Burch, 2009). Academics tend to rank individual achievement above the need to operate as part of a team. Roffe (1998) refers to the 'prima ballerina effect', where academics are reluctant to act in a unified manner. This situation is aggravated by the practices of universities to promote individuals on the basis of their individual research outputs, scholarship and teaching - activities that are highly individual. Academics may at times be prepared to share knowledge to build capacity in a collegial manner and Tapper and Palfreyman (2000) refers to this as 'intellectual collegiality' where academics reach broad consensus about particular matters. This is hardly team work as decision making takes place on an individual level which further perpetuates individualism.

It is thus highly unlikely that intellectual collegiality will contribute to the strengthening of teamwork amongst academics. This is in contrast to private sector organisations where teamwork is a main characteristic (Deloitte, 2017). In this sense teamwork can foster interdependence and a sense of meaning and purpose that might be difficult for universities to achieve with their more individualistic focus. High levels of individuality may further have implications for interdependence, commitment and morale which supports the notion of Davies, et.al (2007) that academic tend to be more committed to the values of their professional bodies than that of the university that employ them.

Another complicating factor is that universities are mostly governed by bureaucratic models which may hinder their responsiveness, agility and speed in adapting to change. As a bureaucratic structuring is internally focused they do not allow for flexibility and a customer-oriented focus. This is problematic in the globalized world of work where change is omnipresent and organisations need to be flexible and agile in adapting to the needs of customers and the external environment. Being listless and rigid can have serious implications for the relevance of universities in the $21^{\text {st }}$ century (Lynch, 2014), 
hence the necessity for universities to critically evaluate the appropriateness of the bureaucratic models they use.

\section{$4 \quad$ Why is workplace spirituality important?}

As contemporary employees want to find purpose and meaning in their jobs the notion of workplace spiritualty has become increasingly prominent. In this sense, workplace spirituality is a dynamic process by which individuals' express personal values within the organisational context in search of a greater sense of meaning and purpose through their connectedness and community with others (Krishnakumar and Neck, 2002). Petchsawanga and Duchon (2009) maintain that the major components of workplace spirituality are meaningful work, purposeful work, sense of community and transcendence.

Literature on workplace spirituality (see Benefiel, 2003; Biberman \& Whitty, 1997; Delbecq, 1999; Eisler \& Montouori, 2003; Fry, 2003; Krishnakumar \& Neck, 2002; Leigh, 1997; Sass, 2000; Wagner-Marsh \& Conely, 1999) postulates a link between workplace spirituality and increased commitment to organisational goals. This includes increased honesty and trust within the organisation, greater kindness and fairness, enhanced creativity, increased profits and improved morale, organisational performance and productivity, as well as reduced absenteeism and turnover.

Benefiel, Fry and Geigle (2014) track the origin of workplace spirituality to the $6^{\text {th }}$ century, where St Benedict (c. 480-543) provided rules for monastic life, integrating work and prayer. During the Industrial Revolution, Protestants developed the 'protestant work ethic' in order to spiritualise the workplace. These actions shows that humans seek purpose and meaning in their work. The post-industrial revolution saw the emergence of economic wealth as an end in itself, devoid of the principles that could enrich an employee's life. Initial research on spirituality was mainly conducted in the fields of Psychology and Psychiatry, with a focus on individual spirituality. The term 'faith at work' developed in the late $19^{\text {th }}$ century in Europe and the United States mainly as a response to the lack of interest that the church displayed toward people's experiences in the workplace (Benefiel, at.al., 2014). The main impetus of this movement was the acknowledgement of the depth and breadth of workplace spirituality and its influence on the success of an organisation.

Mohan and Uys (2006) reiterate that the search for spirituality and its integration with everyday work life has gained momentum during the 1990s as many individuals started to re-examining the meaning of work and the purpose of their lives. This happened mostly in reaction to the corporate greed of the 1980s. More specifically, Neal and Biberman (2003) note that the increase in conferences and workshops on workplace spirituality, as well as numerous books on the topic. This has contributed to a re-examining of the nature 
and meaning of work by many Americans, escalating after the terrorist attcaks on September 11, 2001 (Neal \& Biberman, 2003). Fry and Slocum (2008) even go so far as to regard workplace spirituality as the missing attribute of both organisational performance and individual well-being, where work and spirituality is integrated and where employees are assisted to lead more holistic lives.

Beneficial personal outcomes of workplace spirituality are indicated as increased individual creativity, personal fulfilment, work success, increased joy, peace, serenity and job satisfaction (Tischler, Biberman and McKeage, 2002). According to Marques (2006) the benefits of enhanced spirituality amongst employees is likley to elicid feelings of connectedness with colleagues and the larger organisation which can lead to enhanced commitment and morale. A number of workplace spirituality studies using multiple measures (see Duchon \& Plowman, 2005; Fry and Slocum, 2008; Pawar, 2016; Milliman, Czaplewski and Ferguson, 2003) have consistently found workplace spirituality to have a positive relationship to organisational commitment, job satisfaction and productivity. Other variables that were positively influenced by increased workplace spirituality include organisational effectiveness (Karakas, 2010), leadership (Phipps, 2012) satisfaction and well-being (Pashak \& Laughter, 2012), work values and work ethics (Issa \& Pick, 2011) and social justice (Prior \& Quinn, 2012).

Geigle (2012) reiterates that workplace spirituality has been empirically tested in many organisations across several countries. The findings consistently show the beneficial effect of enhanced workplace spirituality on individuals and organisations. This includes enhanced conscientiousness, better career management, reduced inter-role conflict and frustration, organisation-based self-esteem, employee involvement, retention and ethical behaviour.

\subsection{Integrating workplace spirituality with the organisational levels}

In the organisational context workplace spiritulaity can apply to the individual, group and organisational levels. Perceptions that work is meaningful work is found on an individual level, sense of community is found on a group level and alignment with organisational values on an organisational level. The individual level entails the extent to which employees can obtain internal and external satisfaction through meaning and purpose in their work. The group level relates the sense of community with other employees, while the organisation-wide level refers to the perception of the relationship between the individual and the organisation. This implies that individual employees are likely to experience workplace spirituality in as far as there is alignment between their own values and goals and that of the organisation. Figure 1 below depicts the three levels at which workplace spirituality is evident, as indicated by Milliman, et al. (2003). 


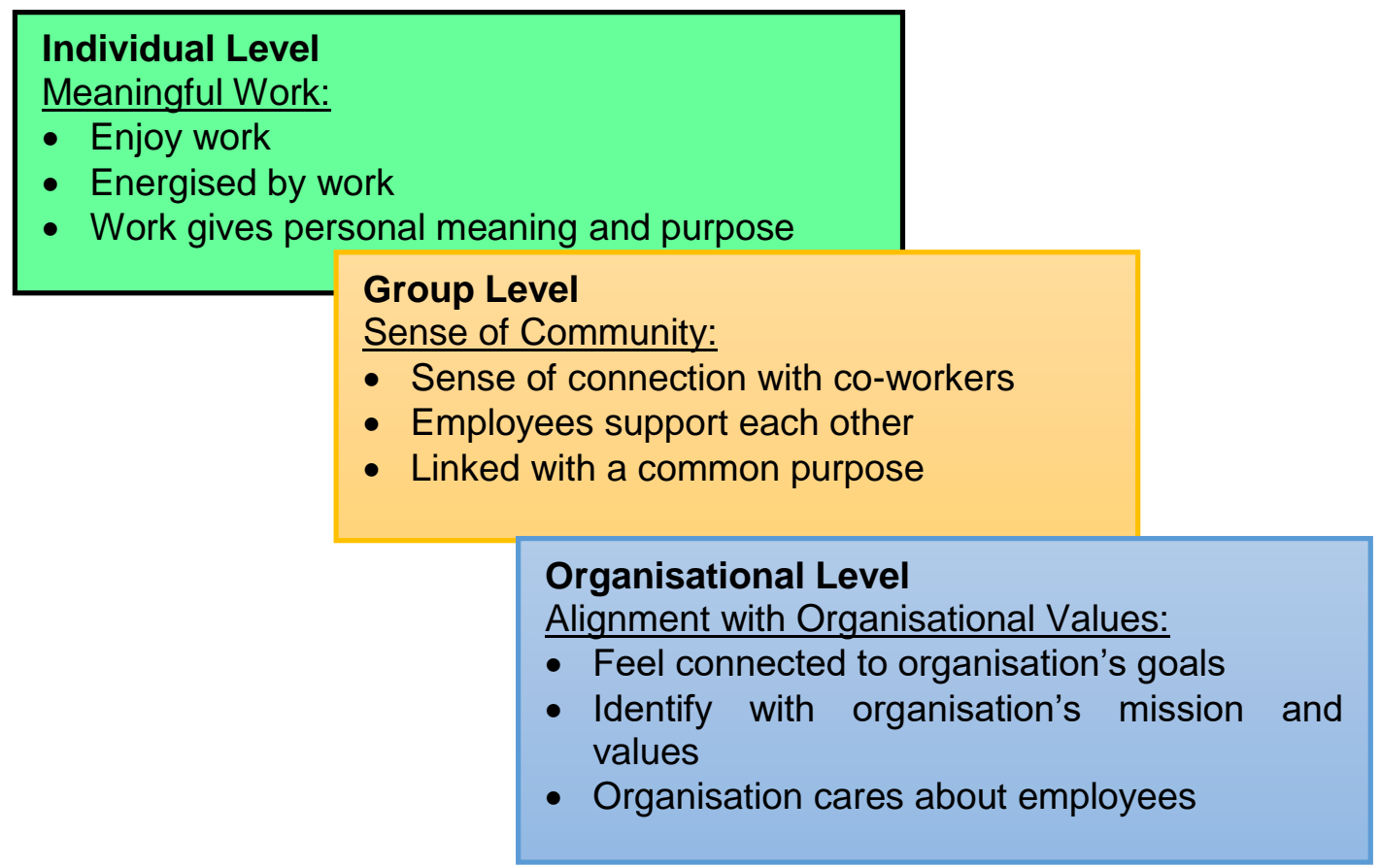

Figure 1: Workplace spirituality and the organisational levels

\section{$5 \quad$ Theoretical framework}

As incdated before Communities of Practice froms the theoretical framework for this discussion. In order to provide a more thorough understanding of Communities of Practice, the work of Lave and Wenger (1991) is useful. They characterise communities of practice in terms of three elements: the domain, the community and the practice. This is explained below.

The domain: The shared domain of interest and membership implies commitment to the domain. Members value their collective competence and learn from each other.

The community: In pursuing their interest in the domain, members engage in joint activities and discussions. As members assist each other and share information they build relationships and learn from each other's best practice, experiences and knowledge.

The practice: Members of a Community of Practice are practitioners and develop a shared repertoire of resources like experiences, stories, tools, etc. commonly referred to as practice. This in itself takes time and continuous interaction.

According to Wenger-Trayner and Wenger-Trayner (2015) a combination of these three elements constitute a Community of Practice. Communities of Practice furthermore form naturally through social learning opportunities and are aimed at the personal and 
professional development of its members. Communities of Practice have two important functions in the conventionalisation of meaning, namely shared experience over time and commitment to shared understanding. Hoadley and Kilner (2005) extend thoughts related to Community of Practice and outline four key practices that relate to the so-called communities' purpose, namely connection, conversation, exploration and documentation of content. Through these practices stronger inter-connectedness is established than that of a community of interest (information sharing). The members of a Community of Practice are held together by a passion for their shared domain.

Communities of Practice can therefore be regarded as crucial towards knowledge sharing and transfer, assimilation, acquisition, exploitation and knowledge transformation. From a theoretical perspective Blackmore (2010) postulates that Communities of Practice advance the values of social learning. Learning per se occurs continuously within organisations as employees learn from their co-worker's behaviour and experiences hence the applicability of Communities of Practice to the discussion.

Communities of Practice provide opportunities for social learning and McDonald and Cater-Steel (2017) state that it has gained interest in universities due to its positive impact and opportunities for social learning across disciplines. Communities of Practice are also increasingly used for professional development. In this regard Wenger-Trayner and Wenger-Trayner (2015) indicate that Communities of Practice offers a fresh perspective on learning and education in general. They maintain that Communities of Practice in universities are leading to new patterns of thinking about the role of educational institutions and the design of learning opportunities.

\section{Discussion}

It is clear from the preceeding discussion that universities have a complex environment that are not necessarily attuned to the promotion of workplace spitituality. As modern universities are characterised by increased managerialism and not the close interdependent relationships and informal structures associated with collegiality this paper makes a case for universities to embrace workplace spirituality as a way of compensaring for diminished collegilaity.

As Communities of Practice implies a shared domain (in this case academic work), a community of scholars (where academics share similar interests and activities) and the practices of shared experiences, tools and stories (related to the academic project) this is likley to ehance the meaning, purpose and connectedness they experience. The crux is thus to engage acedemics on a spiritual level and getting them to engage with each other in enhancing the academic project. Given that academics often prefer individualistic activities above team-related ones, academic and university management need to create 
platforms for continious interaction. This can include platforms to enhance intrapersonal skills and self-reflection, as well as exploring the job as a calling, interpersonal interventions (presented as part of employee development programmes) and group interventions (i.e. spiritual team-building exercises and spiritual leadership development). Communities of Practice are likely to create shared experiences which may lead to a culture of shared values.

Santiago and Carvalho (2012) found through interviewing that most academics still support the traditional collegial values of autonomy and collegiality and reject the use of corporate philosophy. This means that collegial values have not disappeared entirely and can be harnessed to create a spiritual environment. As collegiality is not always attuned with the pressures of making managerial decisions, the challenge to university management is to combine the collegiality ethos with sound managerial principles to ensure that universities remain relevant in the Knowledge Age. There should thus be a balance between the academics' need for collegiality and the organisation's need for accountability.

A balance between collegialism and managerialism is proposed in order to satisfy all stakeholders. Lewis, Marginson and Snyder (2005) point out that universities should respond to managerialism by becoming more collegial and incorporate networking, partnerships, professional bodies and commercial entities as part of their focus. Diverse collegial structures may operate at faculty and school level. This may vary from groups that form naturally (like groups of academics with the same interests) to groups that form when specific issues are to be addressed (like work groups, collaborative research groups, task teams, etc.).

Nickson (2014) found that due to the complexity of what is expected from academics they often pursue their own research agenda witinin the formal university structutes. As the implementation gap between strategic and operational practices may create space for autonomy it may also lead to tension because of conflicting values. The lack of recognition pertaining to the spectrum of activities expected from academics may further lead to confusion and disconnection. The question then arises as to whether managerial activities (like meetings, set agendas, workload, etc.) really fit into what is expected from the academics. Duke (2004) for example, reports resentment on the part of Australian academics towards managerialism emphasising that managerialism creates a compliance culture that may result in low morale amongst academic staff.

\section{Conclusion}

The aim of the paper was to interrogate the potential mitigating effect of managerialism on academics and universities. Given that collegiality is diminishing (although the values 
associated with collegiality are not) the paper made a case for universities to enhance workplace spirituality. By using Communities of Practice as a theoretical framework a link was created between the values associated with workplace spirituality and collegiality. Some tangible suggestions were made to university management to enhance workplace spirituality.

\section{References}

Abramov, R. N. (2012) 'Managerialism and the Academic Profession', Russian Education \& Society. doi: 10.2753/RES1060-9393540304.

Alawaad, A. A. (2015) Examining the employment relationship in UK higher education in a managerialist era, PQDT - UK \& Ireland. Available at:

https://queens.ezp1.qub.ac.uk/login?url=https://search.proquest.com/docview/1827515128?accounti $\mathrm{d}=13374 \% 0$ Ahttp://resolver.ebscohost.com/openurl?ctx_ver=Z39.88-

2004\&ctx_enc=info:ofi/enc:UTF-

8\&rfr_id=info:sid/ProQuest+Dissertations+\%26+Theses+A\%261\&rft_val_f.

Anderson, R. (2010) The 'idea of a university' today: the Italian long 1968. History and Policy. Available at: www.histpol.hist.cam.ac.uk/papers/policy-paper-98.html (Accessed: 22 December 2016).

Benefiel, M. (2003) 'Irreconcilable foes? The discourse of spirituality and the discourse of organizational science', Organization, pp. 383-391. doi: 10.1177/1350508403010002012.

Benefiel, M., Fry, L. W. and Geigle, D. (2014) 'Spirituality and religion in the workplace: History, theory, and research', Psychology of Religion and Spirituality, 6(3). doi: 10.1037/a0036597.

Biberman, J. and Whitty, M. (1997) 'A postmodern spiritual future for work', Journal of Organizational Change Management, 10(2), pp. 130-138. doi: 10.1108/09534819710160790.

Blackmore, J. (2010) 'Preparing leaders to work with emotions in culturally diverse educational communities', Journal of Educational Administration, 48(5), pp. 642-658.

Clark, N. . (2013) The first colleges and universities: A brief history of higher education. Michigan: Guest Post.

Davies, J.; Douglas, A. \& Douglas, J. (2007) 'The effect of academic culture on the implementation of the EFQM excellence model in UK universities.', Quality Assurance in Education: An International Perspective, 15(4), pp. 382-401.

Delbecq, L. A. (1999) 'Christian Spirituality and Contemporary Business Leadership', Journal of Organizational Business Management, 12(4), pp. 345-349. 
Deloitte (2017) 2017 Deloitte Global Human Capital Trends. Available at: https://www2.deloitte.com/content/dam/Deloitte/global/Documents/About-Deloitte/central-europe/ce(Accessed: 15 January 2018).

Duchon, D. and Plowman, D. A. (2005) Nurturing the spirit at work: Impact on work unit performance., Management Department Faculty Publication, 65. Available at: http://digitalcommons.unl.edu/managementfacpub/65.

Duke, C. (2004) 'Is there an Australian idea of a university?', Journal of Higher Education Policy and Management, 26(3), pp. 297-314.

Eisler, R. and Montouori, A. (2003) 'The Human Side of Spirituality', in Giacalone R.A. and Jurkiewicz, C. L. (ed.) Handbook of Workplace Spirituality and Organizational Performance. New York: Armorok, pp. 46-56.

Fry, L. W. (2003) 'Toward a theory of spiritual leadership', Leadership Quarterly, pp. 693-727. doi: 10.1016/j.leaqua.2003.09.001.

Fry, L. W. and Slocum, J. W. (2008) 'Maximizing the Triple Bottom Line through Spiritual Leadership', Organizational Dynamics, 37(1), pp. 86-96. doi: 10.1016/j.orgdyn.2007.11.004.

Geigle, D. (2012) 'Workplace Spirituality Empirical Research: A Literature Review', Business and Management Review, 2(10), pp. 14-27.

Hoadley, C.M., and Kilner, P. G. (2005) Using technology to transform communities of practice into knowledge-building communities. New York: ACM Press.

Issa, T. and Pick, D. (2011) 'An interpretive mixed-methods analysis of ethics, spirituality and aesthetics in the Australian services sector.', Business Ethics: A European Review, 20, pp. 45-58.

Jarvis, D. S. L. (2014) 'Regulating higher education: Quality assurance and neo-liberal managerialism in higher education-A critical introduction', Policy and Society, 33(3), pp. 155-166. doi: 10.1016/j.polsoc.2014.09.005.

Karakas, F. (2010) 'Spirituality and performance in organizations: A literature review', Journal of Business Ethics, 94(1), pp. 89-106.

Krishnakumar, S. and Neck, C. P. (2002) 'The "what", "why" and "how" of spirituality in the workplace', Journal of Managerial Psychology, 17(3), pp. 153-164. doi: 10.1108/02683940210423060.

Lave, J. and Wenger, E. (1991) 'Situated learning: Legitimate peripheral participation', Learning in doing, 95, p. 138. doi: $10.2307 / 2804509$. 
Leigh, P. (1997) ‘The new spirit at work’, Training \& Development, 51, pp. 26-33.

Lewis, T.; Marginson, S. \& Snyder, I. (2005) 'The network university? Technology, culture and organizational complexity in contemporary higher education', Higher Education Quarterly, 59(1), pp. 56-75.

Lynch, K. (2014) 'New managerialism: The impact on education', Concept, 5(3), pp. 1-11.

Lynch, K. (2015) 'Control by numbers: new managerialism and ranking in higher education', Critical Studies in Education, 56(2), pp. 190-207. doi: 10.1080/17508487.2014.949811.

Marques, J. F. (2006) 'The spiritual worker: An examination of the ripple effect that enhances quality of life in- and outside the work environment', Journal of Management Development, 25(9), pp. 884-895. doi: 10.1108/02621710610692089.

McDonald, J. and Cater-Steel, A. (2017) Communities of practice: Facilitating social learning in higher education. Singapore: Springer.

Milliman, J., Czaplewski, A. J. and Ferguson, J. (2003) 'Workplace spirituality and employee work attitudes: An exploratory empirical assessment', Journal of Organizational Change Management, 16(4), pp. 426-447. doi: 10.1108/09534810310484172.

Mohan, D. L. and Uys, K. (2006) 'Towards living with meaning and purpose : spiritual perspectives of people at work', SA Journal of Industrial Psychology, 32(1), p. p.53-59. doi: 10.4102/sajip.v32i1.228.

Nagy, J. \& Burch, T. (2009) 'Communities of practice in academe (CoP-iA): Understanding academic work practices to enable knowledge building capacities in corporate universities', Oxford Review of Education, 35(2), pp. 227-247.

Neal, J. and Biberman, J. (2003) 'Introduction: The leading edge in research on spirituality and organizations', Journal of Organizational Change Management, 16(4), pp. 363-366.

Nickson, A. (2014) 'A qualitative case study exploring the nature of New Managerialism in UK higher education and its impact on individual academics' experience of doing research', Journal of Research Administration VO - 45, (1), p. 47. Available at: http://ezproxy.ace.edu/login?url=http\%3A\%2F\%2Fsearch.ebscohost.com\%2Flogin.aspx\%3Fdirect\% 3Dtrue\%26AuthType\%3Dip\%2Cuid\%26db\%3Dedsgbe\%26AN\%3Dedsgcl.381635877\%26site\%3De ds-live\%26scope\%3Dsite.

Pashak, T.J. and Laughter, T. C. (2012) 'Measuring service mindedness and its relationship with spirituality and life satisfaction.', College Student Journal, 46, pp. 183-192. 
Pawar, B. S. (2016) 'Workplace spirituality and employee well-being: an empirical examination', Employee Relations, 38(6). doi: 10.1108/ER-11-2015-0215.

Petchsawanga, P. \& Duchon, D. (2009) 'Measuring workplace spirituality in an Asian context', Human Resource Development International, 12(4), pp. 459-468.

Phipps, K. A. (2012) 'Spirituality and strategic leadership: The influence of spiritual beliefs on strategic decision making', Journal of Business Ethics, 106, pp. 177-189.

Du Pre, R. (2010) Universities of technology: Deepening the debate. Pretoria: Council on Higher Education (CHE). Available at: http://www.che.ac.za/sites/default/files/publications/Kagisano_No_7_February2010.pdf.

Prior, M.K. and Quinn, A. S. (2012) 'The relationship between spirituality and social justice advocacy: Attitudes of social work students.', Journal of Religion and Spirituality in Social Work: Social Thought, 31, pp. 172-192.

Roffe, I. M. (1998) 'Conceptual problems of continuous quality improvement and innovation in higher education', Quality Assurance in Education: An International Perspective, 6(2), pp. 74-82.

Santiago, R. and Carvalho, T. (2012) 'Managerialism Rhetorics in Portuguese Higher Education', Minerva. doi: 10.1007/s11024-012-9211-9.

Sass, J. S. (2000) 'Characterizing organizational spirituality: An organizational communication culture approach', Communication Studies, 51(3), pp. 195-217. doi: 10.1080/10510970009388520.

Tapper, T. \& Palfreyman, D. (2000) Oxford and the decline of the collegial culture. London: Woburn Press.

Teichler, U., Arimoto, A. and Cummings, W. K. (2013) The changing academic profession: Major findings of a comparative survey, The Changing Academic Profession: Major Findings of a Comparative Survey. doi: 10.1007/978-94-007-6155-1.

Tischler, L., Biberman, J. and McKeage, R. (2002) 'Linking emotional intelligence, spirituality and workplace performance: Definitions, models and ideas for research', Journal of Managerial Psychology, 17(3), pp. 203-218.

Wagner-Marsh, F. and Conely, J. (1999) 'The Fourth Wave: The Spiritually Based FirmNo Title', Journal of Organizational Change Management, 12(4), pp. 292-301.

Wenger-Trayner, E. and Wenger-Trayner, B. (2015) Communities of practice: A brief introduction. Available at: http://wenger-trayner.com/wp-content/uploads/2015/04/07-Brief-introduction-to-communities-ofpractice.pdf. 
Wenger, E. (2004) 'Knowledge management as a doughnut: Shaping your knowledge strategy through communities of practice', Ivey Business Journal, Jan/Feb, pp. 1-8. doi: Article.

Zeleza, P. T. (2016) 'Global Village: The Competitive Challenges of Internationalization', in The Transformation of Global Higher Education, 1945-2015, pp. 213-295. doi: 10.1057/978-1-137-528698 8. 